\section{Water Requirements of Landscape Plants Studies Conducted by the University of California Researchers}

\author{
Janet S. Hartin ${ }^{1,7}$, David W. Fujino ${ }^{2}$, Lorence R. Oki ${ }^{3}$, \\ S. Karrie Reid ${ }^{4}$, Charles A. Ingels ${ }^{5}$, and Darren Haver ${ }^{6}$
}

ADDITIONAL INDEX WORDs. landscape water use, evapotranspiration, landscape irrigation, CIMIS, plant factor, ETAF, WUCOLS

SUMMARY. University of California (UC) researchers have been involved in research and extension pertaining to measuring evapotranspiration (ET) rates and determining the minimum irrigation requirements of landscape plants for more than 30 years. Early work included the design and implementation of the California Irrigation Management Information System (CIMIS) weather station network and determining crop coefficients for warm and cool season turfgrasses based on historical ET and CIMIS data. Other researchers determined the minimum irrigation requirements for several species of established landscape trees, shrubs, and groundcovers in diverse climate zones throughout the state. In addition, the Water Use Classification of Landscape Species (WUCOLS) system was developed by UC personnel in the early 1990s which, to date, has classified more than $\mathbf{3 5 0 0}$ landscape species into very low, low, moderate, and high water-use categories based on observation and personal experience by industry experts and UC personnel. Future work in the area of landscape water use and conservation will include updating WUCOLS as more data from replicated trials become available. New research at UC Riverside aims to improve irrigation efficiency (IE) through precision irrigation using smart controllers, remote sensing, and geospatial analysis under controlled conditions. Irrigation training and certification for public and private landscape managers must remain a priority because, even with advanced smart controller technologies, water savings will not occur with poorly designed and functioning irrigation systems.

$\mathrm{B}$ etween $40 \%$ and $70 \%$ of water used in urban settings in the United States is applied to

This article results from the workshop "Maintaining Healthy Landscapes Under Drought and/or Permanent Water Restrictions" held on 20 Sept. 2017, at the ASHS Annual Conference, Waikoloa, HI and sponsored by the Ornamentals/Landscape and Turf (O/LT) Professional Interest Group.

Appreciation is extended to Workshop fellow presenters Raul Cabrera, Michael Dukes, and Ursula Schuch, session attendees, and the O/LT Professional Interest Group.

Authors received funding from California Department of Water Resources, Saratoga Horticultural Foundation, and Metropolitan Water District of Southern California.

${ }^{1}$ University of California Cooperative Extension, 777 E. Rialto Avenue, San Bernardino, CA 92415

${ }^{2}$ University of California, Davis, 1108 Environmental Horticulture, Davis, CA 95616

${ }^{3}$ University of California, Davis, One Shields Avenue, 1110 Environmental Horticulture, Davis, CA 95616

${ }^{4}$ University of California Cooperative Extension, 2101 E. Earhart Avenue, Suite 200, Stockton, CA 95206

${ }^{5}$ University of California Cooperative Extension, 4145 Branch Center Road, Sacramento, CA 95827

${ }^{6}$ Water Resources Advisor, Orange County, University of California Cooperative Extension, and Director, South Coast Research and Extension Center, Irvine, CA 92618

${ }^{7}$ Corresponding author. E-mail: jshartin@ucanr.edu. https://doi.org/10.21273/HORTTECH04037-18 landscape plantings (Cabrera et al., 2013; Haley et al., 2007; Kjelgren et al., 2000; St. Hilaire et al., 2008). Water conservation in urban landscapes in California is especially important because of a limited water supply, cyclical droughts, population increases, and a water distribution problem requiring transporting large volumes of water from Northern to Southern California. The population of California is expected to increase from 39 to 60 million by 2050 (Dieter and Maupin, 2017). Since 2005, nearly half of the population growth in the state has occurred in inland Southern California and the Central Valley because of less expensive and more plentiful land than along the coast (Hanak and Davis, 2006). In addition, because inland landscapes tend to be larger and
ET rates higher than those in coastal areas, more water is required for their irrigation.

Climate change poses additional challenges to urban landscapes as rising temperatures coupled with limited water exacerbates the need to increase and diversify the palette of trees and other ornamentals adaptable to harsh urban conditions (Bohn et al., 2018; Hanak and Lund, 2008). Furthermore, Fall 2011 through Fall 2015 was the driest 4-year period in recorded history in California since the beginning of weather tracking in 1895 , exacerbated with record high temperatures in 2014 and 2015 (Hanak et al., 2015). Although precipitation in 2016 and 2017 rose to near-average levels in much of northern California, all of central and southern California continue to experience moderate or severe drought as of 10 Mar. 2018 (Fenimore, 2018).

An increase in California's population coupled with a multiyear drought in the 1980s requiring greater landscape water conservation led to the enactment of the California Assembly Bill 325 (Water Conservation in Landscaping Act), which became effective in 1993. The act required the California Department of Water Resources (CDWR) to develop a Model Water Efficient Landscape Ordinance (MWELO), intended to increase water conservation in urban landscapes. This included reducing water waste in landscape plantings and listing landscape plants within WUCOLS water-use categories to supplement the small number of actual plants whose water use had been measured in field studies, a lengthy and resource-intensive process.

The assumed a leadership role in WUCOLS, bringing together $36 \mathrm{ex}-$ perts from the landscape industry who categorized thousands of plants in six climate zones (north central valley, central valley, south coastal, south inland valley, high and intermediate desert, and low desert) as very low, low, moderate, or high water users. Since the inception of WUCOLS, additional species were

\begin{tabular}{llll}
\hline $\begin{array}{l}\text { Units } \\
\begin{array}{l}\text { To convert U.S. to SI, } \\
\text { multiply by }\end{array}\end{array}$ & U.S. unit & SI unit & $\begin{array}{l}\text { To convert SI to U.S., } \\
\text { multiply by }\end{array}$ \\
\hline 0.0929 & $\mathrm{ft}^{2}$ & $\mathrm{~m}^{2}$ & 10.7639 \\
3.7854 & gal & $\mathrm{L}$ & 0.2642 \\
2.54 & inch(es) & $\mathrm{cm}$ & 0.3937
\end{tabular}


added and, when deemed necessary, plants were recategorized (Costello and Jones, 2014; Costello et al., 1991, 2000). Presently, WUCOLS includes more than 3500 plants categorized in its searchable database (Costello and Jones, 2014).

Irrigating landscape plants less than their ET rate is an effective water-saving strategy that has become common in arid states under conditions of drought and water restrictions. Because landscape plants are planted for their ornamental value rather than for producing crops that require large amounts of water at certain life cycle stages, significant water savings can be realized through this practice (Costello et al., 2000; Hartin et al., 1993, 2015). Fortunately, many landscape plants retain acceptable health and appearance when subjected to deficit irrigation (Hartin et al., 1993, 2015; Kjelgren et al., 2000; Montague et al., 2004, 2007; Pittenger et al., 2001, 2002, 2009; Sun et al., 2012).

As previously mentioned, determining the minimum irrigation requirements for the thousands of native and introduced landscape plant species growing in arid climates is a formidable task. Adding to the burden are landscape areas (LAs) that contain plantings of multiple species, planting densities, and microclimates that comprise the vast majority of these landscapes (Nouri et al., 2012, 2016; St. Hilaire et al., 2008). The common agronomic practice of determining crop coefficient $\left(\mathrm{K}_{\mathrm{c}}\right)$ values that relate the water requirement of a specific crop to reference ET illustrated by Eq. [1] is inadequate for correctly estimating irrigation requirements of these complex mixed landscapes (Allen et al., 1998; Nouri et al., 2012; Snyder and Eching, 2006).

$$
\mathrm{ET}_{\mathrm{c}}=\mathrm{ET}_{\mathrm{o}} \times \mathrm{K}_{\mathrm{c}}
$$

In Eq. [1], $\mathrm{ET}_{\mathrm{c}}$ is the water requirement of a specific crop, $\mathrm{ET}_{\mathrm{o}}$ is the reference ET (ET of a healthy, wellwatered cool season turfgrass), and $\mathrm{K}_{\mathrm{c}}$ is a coefficient for a specific crop.

Turfgrass researchers (Gibeault et al., 1985; Harivandi et al., 2009) determined that monocultures of warm and cool season turfgrass plantings that conform to $\mathrm{K}_{\mathrm{c}}$ standards under California conditions have $\mathrm{K}_{\mathrm{c}}$ values of 0.6 and 0.8 , respectively, and often perform adequately at somewhat lower values situationally. A lawn watering guide for the general public based on these $K_{c}$ values, a distribution uniformity (DU) of $80 \%$, and historical $\mathrm{ET}_{\mathrm{o}}$ data were also developed (Hartin et al., 2001). Other work determined that bermudagrasses (Cynodon sp.) and seashore paspalum (Paspalum vaginatum) outperformed several other turfgrasses and alternative groundcovers under deficit irrigation (Gibeault et al., 1989) and quantified the performance of several turfgrass cultivars under varying irrigation regimes and mowing heights (Richie et al., 2002).

Many UC researchers have conducted studies on the health, performance, and aesthetics of non-turfgrass landscape plantings under minimal irrigation conditions. Methods include measuring the performance of monocultures of landscape plants through species evaluations under varying levels of $\mathrm{ET}_{\mathrm{o}}$ and developing WUCOLS for landscapes with mixed species, densities, and microclimates (Costello and Jones, 2014; Costello et al., 1991, 2000). Additional studies have increased the adoption of technologies and practices that reduce water waste in turfgrass and non-turfgrass landscapes, and improve DUs and IE of sprinkler-irrigated landscapes through intense on-site training (Hartin and McArthur, 2007; Hartin et al., 2017; Reid et al., 2017).

A summary and brief review of these UC-led studies follows.

EVAPOTRANSPIRATION ADJUSTMENT FACTOR (ETAF) STUDY. California implemented water conservation legislation that required reductions in urban and agricultural water usage (CDWR, 2009) and added additional water-use constraints for urban landscapes in 2010. A major element of this legislation was the establishment of the California MWELO, which requires the implementation of water budgets based on $\mathrm{ET}_{\mathrm{o}}$, an ETAF, and LA in square feet. A maximum applied water allowance for each site is then calculated, using a 0.62 factor to convert inches to gallons as shown in Eq. [2]:

$$
\mathrm{MAWA}=\mathrm{ET}_{\mathrm{o}} \times \mathrm{ETAF} \times \mathrm{LA} \times 0.62
$$

The $\mathrm{ET}_{\mathrm{o}}$ values are estimated at more than 120 CIMIS weather station sites throughout the state which measure and record temperature, solar radiation, wind speed, and relative humidity hourly with free online access to real-time and historical records. An ETAF further adjusts the $\mathrm{ET}_{\mathrm{o}}$ based on a plant factor (PF) and IE as follows:

$$
\mathrm{ETAF}=\mathrm{PF} \div \mathrm{IE}
$$

Plant factors categorize landscape water use of individual species based on high, moderate, low, and very low categories from the WUCOLS database.

During the mid-2000s, the CDWR funded a UC project to determine the efficacy of reducing the ETAF from 0.8 to 0.7 without sacrificing landscape quality and health. Researchers and a landscape contractor firm with certified irrigation auditors hired by the project selected 30 well-established, professionally maintained, landscapes (parks, school districts, golf courses, and one private residence) in six climate zones corresponding to the six WUCOLS zones throughout the state. The sites contained a variety of plant species mixes, irrigation technologies and practices, planting densities, and microclimates.

Site managers received training from project personnel regarding how to schedule irrigations based on climate and plant water needs using CIMIS and WUCOLS data. Handson demonstrations of best management practices leading to improved IE and reduced water waste were also provided. These included determining sprinkler system precipitation rates and DU, which measures the evenness of applied water across the site; irrigation scheduling; regular site-inspections to check for equipment failure, head misalignment, pressure irregularities, breakage, and other common issues; and proper use of mulch. Total water use of each site was measured by water meters (21 sites) or sensors ( 9 sites) and recorded monthly for 24 months. The sites were inspected quarterly by project personnel who made sprinkler repairs as needed and evaluated plant health and canopy coverage. At the end of the first year, managers of sites that exceeded an ETAF of 0.7 were asked to reduce their water budgets to 0.7 the second (final) year. Coincidentally, mandatory emergency water restrictions were imposed by the state during the second year of the study, 
limiting the days and hours in which landscapes could be irrigated.

Twenty-one of the 30 project sites met the 0.7 ETAF goal by the end of the study (Hartin et al., 2017; Reid et al., 2017). All 14 turfgrass sites reduced water use by an average of $19 \%$. Distribution uniformity increased on the turfgrass sites, an average of $13 \%$. However, even with a sprinkler system IE of 75\% (meeting statewide standards), which was attained at some turfgrass sites, only six sites maintained acceptable quality. Cool season turfgrasses performed the worst, particularly in hotter inland and desert areas. Only sites planted with warm season turfgrass performed adequately at $50 \% \mathrm{ET}_{\mathrm{o}}$, consistent with other studies indicating the higher water requirement for cool season grasses (Gibeault et al., 1985, 1989).

All 24 shrub sites used considerably less water than the turfgrass sites, although 10 shrub sites increased water use the second year (ETAFs of 0.58 and 0.61 ) because of malfunctioning valves at some sites, and management turnover leading to a lack of continuity in site maintenance at other sites. Plant quality was acceptable at or less than the targeted 0.7 ETAF at all shrub sites throughout the 2-year study.

Overall, study results indicate that landscapes planted in mixtures of medium, low, and very low water requiring landscape species that are drip irrigated and mulched can include small areas of warm season sprinkler-irrigated turfgrass and perform adequately at 0.70 ETAF. Landscapes planted in very low and low water-requiring species can include small areas of warm season turfgrass and function adequately at the current 0.55 ETAF. The study also underscores the importance of proper selection, installation, and maintenance of irrigation equipment, including regular equipment inspection and catchment tests to improve DU on turfgrass sites. The large amount of water waste that occurred on many of the study sites before intervention in the second year is not uncommon on large landscape sites. Findings are consistent with those from other studies showing that, in some cases, more water is wasted from equipment malfunctions and poor DUs than is potentially saved from proper plant selection and irrigation scheduling based on the climate and species (Baum et al., 2003; Hartin and McArthur, 2007; Hartin et al., 2017; Reid et al., 2017).

These results also underscore the importance of allowing exemptions from mandated water budgets for "special landscape areas" which include recreational turfgrass (sports fields and parks), edibles, and plants irrigated with recycled water. Research indicates that living turfgrass surfaces perform better than synthetic (artificial) surfaces under recreational wear, particularly in hotter climates (Petrass et al., 2014). Artificial surfaces also tend to result in more player injuries (McNitt et al., 2008; Serensits et al., 2011; Williams and Pulley, 2003). For jurisdictions not allowing "opt-out" clauses for recreational turfgrass, options to meet reduced water budgets include decreasing the percentage of cool season turfgrass, replacing cool season turfgrass with warm season turfgrass, and replacing turfgrass with drip-irrigated ornamentals.

Plant PERformance trials $\left(\mathrm{ET}_{\mathrm{O}}\right.$ AND PF). UC researchers verified that two species of landscape trees, indian laurel fig (Ficus nitida 'Green Gem') and sweetgum ( $\mathrm{Liq}^{-}$ uidambar styraciflua), often irrigated at $60 \%$ to $120 \% \mathrm{ET}_{\mathrm{o}}$, performed optimally at $20 \%$ and $40 \% \mathrm{ET}_{\mathrm{o}}$ compared with $60 \%, 80 \%$, and $100 \% \mathrm{ET}_{\text {o }}$ in a replicated 5 -year study during the 6-year drought (1987-92) at the South Coast Research and Extension Center in Irvine, CA (Hartin et al., 1993). A third tree in the study, holly oak (Quercus ilex), performed significantly better at $20 \%$ and $40 \% \mathrm{ET}_{\mathrm{o}}$ due largely to root loss caused by Phytophthora species when trees were irrigated at $60 \%, 80 \%$, and $100 \% \mathrm{ET}_{\mathrm{o}}$. A fourth species, carrotwood (Cupaniopsis anacardioides), sustained substantial wind damage and was not evaluated after the initial year of planting. Other UC researchers determined that three of six species of groundcover assessed, dwarf coyote brush (Baccharis pilularis 'Twin Peaks'), hairy dewflower (Drosanthemum hispidum), and english ivy (Hedera helix 'Needlepoint'), maintained aesthetic acceptability at 20\% $\mathrm{ET}_{\mathrm{o}}$. In the same study, blue periwinkle (Vinca major) performed adequately at $30 \% \mathrm{ET}_{\mathrm{o}}$ (Pittenger et al., 2001). Another study found that all the studied palm species [king palm (Archontophoenix cunninghamiana), mediterranean fan palm (Chamaerops bumilis), queen palm (Syagrus romanzoffiana), chinese windmill palm (Trachycarpus fortunei), and california fan palm (Washingtonia filifera)] that received $50 \% \mathrm{ET}_{\mathrm{o}}, 25 \% \mathrm{ET}_{\mathrm{o}}$, or no irrigation after ample irrigation the first 2 years maintained acceptable visual quality under the reduced $\mathrm{ET}_{\mathrm{o}}$ levels the third year of the study; mediterranean fan and california fan palms performed nearly optimally with no irrigation.

Another team of UC researchers has been conducting 2-year irrigation trials on a continuing basis at UC Davis and other sites in several climate zones throughout the state that have, to date, determined the minimum irrigation requirements of more than 150 species of landscape ornamentals under conditions of full sun or $50 \%$ shade. Plants selected for the trials are transplanted to the field from containers in November and irrigated through the establishment period at $80 \%$ to $100 \% \mathrm{ET}_{\mathrm{o}}$. From April through October during the second year of the studies, irrigation was decreased to $80 \%, 60 \%, 40 \%$, or $20 \%$ $\mathrm{ET}_{\mathrm{O}}$ in the replicated trials (Oki et al., 2016; Reid and Oki, 2008, 2013). Data collected include plant health and height, width, and length in addition to esthetic qualities. Results correspond favorably with those from other UC trials, indicating that several species of native and climate-adapted non-native ornamentals perform well at $20 \% \mathrm{ET}_{\mathrm{o}}$ once established. Examples include snowy river wattle (Acacia boormanii); california lilac (Ceanothus $\times$ pallidus 'Marie Simon'), island mountain mahogany (Cercocarpus betuloides 'Blancheae'), pine muhly (Mublenbergia dubia), blue bedder (Penstemon heterophyllus), tangerine stalked bulbine (Bulbine frutescens 'Tiny Tangerine'), cabbage tree (Cordyline australis 'Purple Sensation'), yellow monkeyflower (Mimulus 'Curious Georgie Boy'), st. john's wort (Hypericum androsaemum 'Ignite Red'), purple ice plant (Delosperma cooperi), bladderpod (Isomeris arborea), japanese holly fern (Cyrtomium falcatum), walking iris (Neomarica caerulea), california lilac (Ceonothus 'Concha'), small cape rush (Chondropetalum tectorum), and pink australian fuchsia (Correa pulchella 'Pink Eyre') (Oki et al., 2016; Sisneroz et al., 2018). In some cases, plants such as snowy river wattle, california lilac, 
island mountain mahogany, and blue bedder performed optimally when irrigated at $20 \% \mathrm{ET}_{\mathrm{o}}$ (Reid and Oki, 2013).

\section{Conclusions and "next steps"}

Although much has been accomplished in the realm of reducing water use while maintaining acceptable health, function, and appearance of heterogeneous landscape plantings, more work is necessary to refine current recommendations to industry professionals. Although UC researchers have, to date, determined the minimum water requirements of nearly 200 landscape species in replicated trials, the process is time-consuming and assessing the water requirements of the $\approx 3250$ remaining plants in the WUCOLS database in a timely way is unrealistic. Conversely, the use of WUCOLS, which classifies plants into water-use categories based on observation and experience by experts in the field rather than actual data derived from replicated trials (in most cases) offers a large database. Although not intended to become mandated, dozens of cities and other jurisdictions now require the use of WUCOLS for project approval.

More long-term studies under replicated conditions are needed in California, and elsewhere, to determine the reliability of WUCOLS and $\mathrm{PF}$ methods for estimating minimum irrigation requirements of heterogeneous landscape plantings. Although criticism of the lack of science-based foundation for WUCOLS exists, few replicated studies have been conducted to determine its efficacy. One such study found WUCOLS to accurately predict actual water needs more closely than two other observation-based ET estimation methods aimed at estimating the water requirement of urban landscapes: a PF technique and a crop stress factor technique based on guidelines from Irrigated Public Open Space (Nouri et al., 2012). Subsequently, another study comparing WUCOLS and an enhanced vegetation index (EVI) remote sensing method with a detailed soil water balance (SWB) analysis for 1 year in a heterogeneous landscape consisting of several plant species, planting densities, and microclimates found the EVI method to closely parallel the SWB estimate of water consumption while WUCOLS underestimated it (Nouri et al., 2016). One explanation for varying results is that although SWB methods may indeed closely approximate the water consumption of a mixed planting under conditions of unlimited water, plant quality, and performance of the same species under the same conditions may remain acceptable using the WUCOLS protocol because WUCOLS categorizes plants based on performance under minimum irrigation rather than maximum water consumption.

More work on the use of smart irrigation controllers based on $\mathrm{ET}_{\mathrm{o}}$ and soil moisture depletion under dry California conditions is also important. Although several studies measuring the potential water savings of smart controller technology have shown impressive savings of up to $70 \%$ under controlled conditions, the actual water reduction under more typical landscape conditions (particularly in urban residential rather than commercial settings) averages less than 10\% (Dukes, 2012). A newly implemented study at UC Riverside led by Amir Haghverdi that includes four multiyear turf irrigation trials will refine best practices to identify minimum irrigation requirements using smart irrigation technologies (soil moisture-based and ET-based), RS and geospatial analysis under controlled conditions monitored by a network of time-domain reflectometry soil moisture sensors that will continuously monitor soil water status within and below the root zone.

Another large water waster continues to be low sprinkler system DUs and water losses due to poorly designed irrigation systems, equipment malfunction, pressure issues, and other failures that result in the underperformance of both the sprinkler and drip systems. Ensuring that irrigation systems are properly installed and maintained can lead to more water savings than irrigation based on climate and plant water needs (Hartin and McArthur, 2007; Hartin et al., 2017; Pitts et al., 1996; Reid et al., 2017).

\section{Literature cited}

Allen, R.G., L.S. Pereira, D. Raes, and M. Smith. 1998. Crop evapotranspiration: Guidelines for computing crop water requirements. FAO Irr. Drainage Paper 56.

Baum, M.C., M.D. Dukes, and G.L. Miller. 2003. Residential irrigation uniformity and efficiency in Florida. Amer. Soc. Agr. Eng., Florida Section Mtg. Paper FL03-100.
Bohn, S., D. Bonner, C. Chappelle, M. Mejia, C. Danielson, A. Escriva-Bou, G. Nao, B. Gray, E. Hanak, and L. Hill. 2018. California faces growing water management challenges. Public Policy Inst. California, San Francisco, CA.

Cabrera, R.I., K.L. Wagner, and B. Wherley. 2013. An evaluation of urban landscape water use in Texas. Tex. Water J. 4(2):14-27.

California Department of Water Resources. 2009. Model water efficient landscape ordinance. 20 May 2018. <https://www.water. ca.gov/LegacyFiles/wateruseefficiency/ docs/MWELO09-10-09.pdf>.

Costello, L.R. and K.S. Jones. 2014. WUCOLS IV: Water use classification of landscape species. 20 May 2018. <http:// ucanr.edu/sites/WUCOLS/>.

Costello, L.R., N.P. Matheny, and J.R. Clark. 1991. Estimating water requirements of landscape planting; the landscape coefficient method. Univ. California, Div. Agr. Natural Resources Publ. 21492.

Costello, L.R., N.P. Matheny, and J.R. Clark. 2000. The landscape coefficient method. In: A guide to estimating irrigation water needs of landscape planting in California. 20 May 2018. <http://www. water.ca.gov/wateruseeffciency/docs/ wucols00.pdf $>$.

Dieter, C.A. and M.A. Maupin. 2017. Public supply and domestic water use in the United States, 2015. U.S. Geological Survey Open-File Rpt. 2017-1131. 20 May 2018. <https://pubs.er.usgs.gov/ publication/ofr20171131>.

Dukes, M.D. 2012. Water conservation potential of landscape irrigation smart controllers. Trans. Amer. Soc. Agr. Bion. Eng. 55:563-569.

Fenimore, C. 2018. Drought monitor. 20 May 2018. <http://droughtmonitor.unl. edu/CurrentMap/StateDroughtMonitor. aspx? $\mathrm{CA}>$.

Gibeault, V.A., J.L. Meyer, R. Autio, and R. Strohman. 1989. Turfgrass alternatives with low water needs. Calif. Agr. 43(6): 20-22.

Gibeault, V.A., J.L. Meyer, V.B. Youngner, and S.T. Cockerham. 1985. Irrigation of turfgrass below replacement of evapotranspiration as a means of water conservation; performance of commonly used turfgrasses. Proc. 5th Intl. Turfgrass Res. Conf. 347356.

Haley, M.B., M.D. Dukes, and G.L. Miller. 2007. Residential irrigation water use in central Florida. J. Irr. Drain. Eng. 133:427-434.

Hanak, E. and M. Davis. 2006. Lawns and water demand in California. California 
economic policy. Vol. 2. Public Policy Inst. California, San Francisco, CA.

Hanak, E. and J.R. Lund. 2008. Adapting California's water management to climate change. Public Policy Inst. California, San Francisco, CA.

Hanak, E., J. Mount, and C. Chappelle. 2015. California's latest drought. Public Policy Inst. California, San Francisco, CA.

Harivandi, M.A., J. Baird, J. Hartin, J.M. Henry, and D. Shaw. 2009. Managing turfgrass during drought. Univ. California, Div. Agr. Natural Resources Publ. 8395.

Hartin, J.S. and K.A. McArthur. 2007. Conserving water and improving plant health in large southern California landscapes. Final project report. California Dept. Water Resources Office Water Use Efficiency, Sacramento, CA.

Hartin, J.S., J.L. Meyer, and V.A. Gibeault. 1993. Minimum irrigation requirements of four species of landscape trees. Research report. Univ. California, Agr. Natural Resources, South Coast Field Station, Irvine, CA.

Hartin, J.S., J.L. Meyer, and V.A. Gibeault. 2001. Lawn watering guide. Univ. California Div. Agr. Natural Resources Publ. 8044.

Hartin, J., L. Oki, D. Fujino, and B. Faber. 2015. Drought tip: Keeping plants alive during drought and/or water restrictions. Univ. California, Div. Agr. Natural Resources Publ. 8553.

Hartin, J., L. Oki, D. Fujino, K. Reid, C. Ingels, and D. Haver. 2017. Evapotranspiration adjustment factor study: Final project report. California Dept. Water Resources Office Water Use Efficiency, Sacramento, CA.

Kjelgren, R., L. Rupp, and D. Kilgren. 2000. Water conservation in urban landscapes. HortScience 35:1037-1040.

McNitt, A.S., D.M. Petrunak, and T.J. Serensits. 2008. Temperature amelioration of synthetic turf surfaces through irrigation. Acta Hort. 783:573-581.

Montague, T., R. Kjelgren, R. Allen, and D. Wester. 2004. Water loss estimates for five recently transplanted tree species in a semi-arid climate. J. Environ. Hort 22:189-196.

Montague, T., C. McKenney, M. Maurer, and B. Winn. 2007. Influence of irrigation volume and mulch on establishment of selected shrub species. Arboricult. Urban For. 33:202-209.

Nouri, H., S. Beecham, F. Kazemi, and A. Hassanli. 2012. A review of ET measurement techniques for estimating the water requirements of urban landscape vegetation. Urban Water J. 10:247-259.

Nouri, H., E.P. Glenn, S. Beecham, S. Chavoshi, S. Boroujeni, P. Sutton, S. Alaghmand, B. Noori, and P. Nagler. 2016. Comparing three approaches of evapotranspiration estimation in mixed urban vegetation: Field-based, remote sensing-based and observational-based methods. Remote Sens. 8:492.

Oki, L.R., K. Reid, and J. Sisneroz. 2016. Landscape plant irrigation trials. Acta Hort. 1140:145-150.

Petrass, L.A., D.M. Twomey, and J. Harvey. 2014. Understanding how the components of a synthetic turf system contribute to increased surface temperature. Procedia Eng. 72:943-948.

Pittenger, D.R., J. Downer, D. Hodel, and M. Mochizuki. 2009. Estimating water needs of landscape palms in Mediterranean climates. Hort Technology 19:700-704.

Pittenger, D.R., W.E. Richie, and D.R. Hodel. 2002. Executive summary: Performance and quality of landscape tree species under two irrigation regimes, p. I6-I7. In: R.L. Green, D.R. Pittenger, and W.E. Richie (eds.). Turfgrass and landscape irrigation studies progress report. Univ. California Coop. Ext., Riverside.

Pittenger, D.R., D.A. Shaw, D.R. Hodel, and D.B. Holt. 2001. Responses of landscape groundcovers to minimum irrigation. J. Environ. Hort. 19:78-84.

Pitts, D., K. Peterson, G. Gilbert, and R. Fastenau. 1996. Field assessment of irrigation system performance. Appl. Eng. Agr. 12:307-313.

Reid, K., D. Fujino, L. Oki, J. Hartin, B. Baker, and B. Duenow. 2017. Maintaining urban landscape health and services on reduced irrigation: A multi-site study in best management practices. ISHS lst Intl. Symp. Greener Cities for More Efficient Ecosystem Services in a Climate Changing World, abstr. S2C5, p. 103. 31 May 2018. <https://docs.wixstatic.com/ugd/aa54ce e065d07c2 lf84e2aa481c80e9baefb4f. pdf $>$.

Reid, S.K. and L.R. Oki. 2008. Field trials identify more native plants suited to urban landscapes. Calif. Agr. 62(3):97-104.

Reid, K. and L. Oki. 2013. Irrigation and climate zone trials of perennial plants for sustainable landscapes. Acta Hort. 980: 95-102.

Richie, W.E., R.L. Green, G.J. Klein, and J.S. Hartin. 2002. Tall fescue performance is influenced by irrigation scheduling, cultivar, and mowing height. Crop Sci. 42:2011-2017.

Serensits, T.J., A.S. McNitt, and D.M. Petrunak. 2011. Human health issues on synthetic turf in the USA. J. Sports Eng. Technol. 225:139-146.

Sisneroz, J., L. Oki, D. Fujino, and K. Reid. 2018. UC landscape plant irrigation trials. California Center for Urban Horticulture. 22 May 2018. <https://ccuh. ucdavis.edu/sites/g/files/dgvnsk1376/ files /inline-files / Trials $\% 20$ Overview $\%$ 20Printer\%20Friendly.pdf>.

Snyder, R.L. and S. Eching. 2006. Urban landscape evapotranspiration. Vol. 4: Reference guide, p. 691-693. In: California water plan update 2005. California Dept. Water Resources Bul. 160-05.

St. Hilaire, R., M. Arnold, D.C. Wilkerson, D.A. Devitt, B.H. Hurd, B.J. Lesikar, V.I. Lohr, C.A. Martin, G.V. McDonald, R.L. Morris, D.R. Pittenger, D.A. Shaw, and D.F. Zoldoske. 2008. Efficient water use in residential urban landscapes. HortScience 43:2081-2092.

Sun, H., K. Kopp, and R. Kjelgren. 2012. Water-efficient urban landscapes: Integrating different water use categorizations and plant types. HortScience 47:254-263.

Williams, C.F. and G.E. Pulley. 2003. Synthetic surface heat studies. 22 May 2018. <http://cahe.nmsu.edu/programs/ turf/documents/brigham-young-study. pdf>. 